\title{
Does Vitamin D Deficiency in Different Periods of Gestation Have the Same Effect on Preterm Birth? A Systematic Review and Meta-Analysis
}

\author{
bin Yi ( $\nabla 731831913 @ q q . c o m)$ \\ Gansu Provincial Maternity and Child-care Hospital \\ Rui-han Lian \\ Gansu Provincial Maternity and Child-care Hospital \\ Ping-an Qi \\ Gansu Provincial Maternity and Child-care Hospital \\ Tao Yuan \\ The First Hospital of Lanzhou University \\ Pei-jing Yan \\ Gansu Provincial Hospital \\ Wen-wen Qiu \\ Gansu University of Chinese Medicine \\ Meng Wang \\ Lanzhou University \\ Ying Wei \\ Gansu University of Chinese Medicine \\ Jie Qiu \\ Gansu Provincial Maternity and Child-care Hospital \\ Ya-guang Hu \\ Gansu Provincial Maternity and Child-care Hospital \\ Ke-hu Yang \\ Lanzhou University
}

\section{Research article}

Keywords: vitamin D deficiency, different periods of gestation, preterm birth, meta-analysis

Posted Date: March 2nd, 2020

DOI: https://doi.org/10.21203/rs.3.rs-15534/v1

License: @ (i) This work is licensed under a Creative Commons Attribution 4.0 International License. Read Full License 


\section{Abstract}

Background: Current studies suggest that vitamin D deficiency during pregnancy can produce a certain effect for preterm birth, but there is no research showing whether vitamin $D$ deficiency has a consistent effect in different pregnancies; thus, we conducted a systematic review and meta-analysis of 24 observational studies, grouping them according to the gestational age at the time of serum sampling, to investigate whether vitamin D deficiency in different periods of gestation has different effects on preterm birth and to provide an evidence-based basis for pregnant women to measure and supplement vitamin $D$.

Methods: The databases PubMed-Medline, EMBASE, the Cochrane Library, Web of Science, EBSCO, CBM, and CNKI were searched until July 2019. Two researchers independently assessed the eligibility and quality of studies, and STATA 12.0 software was used for meta-analysis.

Result: Seven cohort studies, 13 case-control studies, and four cross-sectional studies were included from 2500 articles by inclusion and exclusion criteria. After adjusting for age, race, and other confounding factors, meta-analysis results showed that vitamin $D$ deficiency in the first trimester, the second trimester and the third trimester did not increase the risk of preterm birth (odds ratio $(\mathrm{OR})=1.01,95 \%$ confidence interval $(\mathrm{Cl})(0.88,1.16), \mathrm{P}=0.867 ; \mathrm{OR}=1.12,95 \% \mathrm{Cl}(0.92,1.37), \mathrm{P}=0.249 ; \mathrm{OR}$ $=1.05,95 \% \mathrm{Cl}(0.87,1.27), \mathrm{P}=0.602)$. However, there was moderate heterogeneity in the study of vitamin $\mathrm{D}$ deficiency in the second trimester, and subgroup analysis suggested that vitamin D deficiency in the second trimester may increase the risk of preterm birth $(\mathrm{OR}=1.33,95 \% \mathrm{Cl}(1.15,1.54), \mathrm{P}=0.000)$. A sensitivity analysis of the second trimester showed that excluding any one study did not significantly change the results.

Conclusions: Vitamin D deficiency in early and late pregnancy may not be associated with preterm birth, while vitamin D deficiency in middle pregnancy is likely to have an important effect on preterm birth. Vitamin D levels should be measured in the second trimester of pregnancy, and vitamin D supplements should be provided if necessary.

\section{Background}

The World Health Organization (WHO) defines preterm birth (PTB) as a baby born before 37 weeks of gestation, meaning fewer than 259 days from the first day of a woman's last menstrual period [1]. Preterm birth is the most common cause of neonatal death worldwide and the second most common cause of death among children under 5 years of age [2], and is one of the major health indicators in a country. According to the WHO, preterm birth rates in countries range from 5\% to $18 \%$ [3]. Because the fetus cannot realize its growth potential in utero [4], direct or hidden adverse consequences will be generated for future growth and development. The incidence of necrotizing enterocolitis, retinopathy, neonatal jaundice, hypoxic ischemic encephalopathy and other diseases in premature infants was significantly higher than in term infants. Up to $40 \%$ of premature survivors have bronchopulmonary dysplasia, while cerebral palsy, epilepsy, cognitive impairment and other neurological diseases often occur in premature infants [5]. Pregnant women with high risk factors such as smoking, obesity and gestational diseases are more likely to give birth prematurely, and even among healthy women, a certain percentage of babies may be born prematurely [4]. The risk factors of preterm birth are complex, and the prevention of preterm birth is a global health problem $[2,6]$.

Vitamin D is a lipid soluble metabolite which plays an important role in maintaining calcium and phosphorus homeostasis and promoting bone metabolism. In recent years, the role of vitamin D in extracellular health has been paid more and more attention. In terms of metabolism during pregnancy, there is a good deal of research and controversy regarding the effects of vitamin $D$ levels during pregnancy on fetuses and neonates $[7,8]$. Vitamin $D$ deficiency during pregnancy is common around the world [8]. It has been linked to an increased incidence of poor maternal and fetal outcomes, mainly preeclampsia, gestational diabetes, low birth weight and preterm birth [9]. A systematic evaluation of the relationship between vitamin D deficiency during pregnancy and preterm birth in 2016 [10] showed that pregnant women with vitamin D deficiency during pregnancy had an increased risk of preterm birth. According to the updated systematic evaluation on this issue in 2017 [11], circulatory 25-OH D deficiency in pregnant women could increase the risk of preterm birth, and vitamin $\mathrm{D}$ supplementation 
alone during pregnancy can reduce the risk of preterm birth. Although systematic reviews have analyzed the relationship between vitamin $D$ deficiency during pregnancy and preterm birth, no studies have shown a relationship between vitamin $D$ deficiency during different pregnancies and preterm birth. Additionally, high-quality meta-analysis has been increasingly regarded as one of the key tools to obtain evidence $[12,13]$. Therefore, we performed a meta-analysis combining all available data from available observational studies to obtain a more accurate estimate of the effect of vitamin $D$ levels during different pregnancies on the risk of preterm birth.

\section{Methods}

The Consortium on Vitamin D and Pregnancy is a collaboration of prospective birth cohorts that aims to study the association of the function of maternal vitamin $D$ in different periods of gestation with adverse pregnancy and child outcomes. For the current study, we followed preferred reporting items for systematic reviews and meta-analyses (PRISMA) [14-16] guidelines (see supplementary materials), which helped to improve the integrity of this review. A Measurement Tool to Assess systematic Reviews (AMSTAR 2) was used to assess the methodological quality of this study $[17,18]$.

\subsection{Search Strategies}

To identify studies for inclusion, we conducted a systematic literature search for articles on the association of vitamin D with preterm birth published from the database's inception to July 7, 2019, without language restrictions, using the PubMedMedline, EMBASE, the Cochrane Library, Web of Science, EBSCO, CBM and CNKI databases. Additional relevant studies were identified from the list of references from the included publications. Search terms included a mix of medical subject headings (MeSH) and free-text words. We used the PICOS model [19], which means P (participant), I (intervention), C (comparison), 0 (outcome), S (study design); to determine the inclusion criteria, as follows: I (intervention) -"vitamin D, cholecalciferol, ergocalciferol, 25-hydroxy-vitamin D, 25(OH)D”, O (outcome) -“premature birth, preterm birth, premature labor, preterm labor, premature delivery, preterm delivery, prematurity" (see supplementary materials).

\subsection{Inclusion and Exclusion Criteria}

Studies were selected only if they satisfied the following criteria: (1) they were cohort studies, case-control studies and crosssectional studies; (2) the population was pregnant women without chronic disease, HIV infection or depressive symptoms; (3) they included pregnant women of any gestational age, and the duration of pregnancy was determined based on the date of the last menstruation, or by ultrasound; (4) maternal blood samples were taken for assays of 25(OH)D in three periods: the first trimester, which extends through completion of 14 weeks, the second, through 28 weeks, and the third, including the 29th through 42nd weeks of pregnancy [20]; (5) vitamin D deficiency was defined as a 25(OH)D level below $20 \mathrm{ng} / \mathrm{mL}$; (6) PTB was defined as delivery of a live born neonate before 37 weeks of gestation; (7) sufficient data were provided to calculate the effect of gestational 25(OH)D status on PTB; and (8) studies published in English or Chinese. Exclusion criteria were as follows: (1) systematic reviews, meta-analyses, case report, letters, conference abstracts, et al.; (2) animal experiments; (3) duplicate data; (4) vitamin D supplementation during pregnancy as a control study; and (5) the gestational week of blood sample was not clear, including not described or involving two period trimesters of pregnancy (i.e., 12-24weeks).

\subsection{Study Selection and Data Extraction}

All titles and abstracts from the search were cross-referenced to identify duplicates. Titles and abstracts were screened for a subsequent full-text review. After the full text review, the papers included were retained for data extraction. From all the eligible studies, the following key information was extracted by means of a standard format: the first author's last name, year of publication, title and journal of publication, study design, the country (province or city) and time in which the study was performed, the source and number of participants, age of participants, gestational age at serum sampling, assay method of serum 25(OH)D, diagnostic criteria of vitamin D deficiency, diagnosis criteria of PTB, and possible confounding factors in adjustment. Primary outcomes were the total level of vitamin D deficiency, total number of preterm births, and the level of vitamin $\mathrm{D}$ deficiency associated with preterm births. 
During study selection and data extraction, two authors (Rui-han Lian and Ping-an Qi) independently assessed the studies, and disagreements were resolved through discussions between them or with a third author (Tao Yuan).

\subsection{Quality Assessment}

A nine-star system based on the Newcastle-Ottawa Scale (NOS) [21] was used to assess the quality of cohort studies and case-control studies in meta-analysis. The scoring system summarized three major aspects (selection, comparability and outcome) and eight detailed items. High-quality studies were defined as scoring 6 or more of 9 total points [22].

The Agency for Healthcare Research and Quality (ARHQ) methodology checklist was used for cross-sectional studies, which included 11 items with a summary judgement $[23,24]$.

Two different authors (Rui-han Lian and Ping-an Qi) independently appraised the risk of bias of the included studies, and disagreements were resolved by consensus or discussion with a third author (Tao Yuan).

\subsection{Statistical Analysis}

Binary data were combined and effect sizes were presented as ORs (odds ratios) with 95\% confidence intervals (Cls). Forest plots were generated to illustrate the study-specific effect sizes along with a 95\% Cl. Heterogeneity across studies was measured by the Q-test and the $\mathrm{I}^{2}$ statistic (degree of heterogeneity). If the p-value from the Q-test was less than 0.1 and/or the $\mathrm{I}^{2}$ was greater than $25 \%$, heterogeneity across studies was presented. In detail, it was determined that the values of $25 \%$, $50 \%$ and $75 \%$ in the $1^{2}$ test corresponded to low, moderate and high levels of heterogeneity, respectively [25]. We used a fixed effect model (Mantel-Haenszel method) if there was no heterogeneity across studies; otherwise, the random effect model was applied.

Subgroup analysis was used to analyze the possible sources of heterogeneity. Sensitivity analysis was conducted by removing individual studies one by one to observe the influence of each study on the combined effect size. If 10 or more studies are included, Funnel plots and Begg's tests [26] were used to evaluate potential publication bias. All statistical analyses were performed using STATA/SE Version 12.0 (StataCorp, College Station, TX, USA). A p-value < 0.05 was considered as statistically significant for all tests except for the heterogeneity test, in which a p-value $<0.10$ was used.

\section{Results}

\subsection{Search Results}

The detailed steps of the study selection are given as a PRISMA flow diagram in Figure 1. A total of 2498 abstracts were retrieved from the databases, and two studies was added from the references; 1639 were excluded after reading titles and/or abstracts, and 75 articles were subjected to a full-text review. After reading the full text, a total of 24 cohorts were invited to participate, which included 13 cohort studies [27-39], seven case-control studies [40-46] and four cross-sectional studies [4750]. Because three studies [29-31] of 24 measured serum 25(OH)D concentrations at two or three periods of pregnancies, our meta-analysis included nine studies $[28-31,36,39,41,44,46]$ in the first trimester, 11 studies $[27,30-35,37,38,40,43]$ in the second trimester, and nine studies [29-31,42,45,47-50] in the third trimester.

\subsection{Study Characteristics}

The full list of studies included [27-50] and their main characteristics are shown in Table 1. The included studies from the United States, Canada, Australia, New Zealand, Spain, Netherlands, Swedish, Poland, Brazil, Kenya, China, Singapore and Thailand. A total of nine studies [28,30,31,33,37,40,48-50] were from Asian countries, six [36,41,43,45-47] from American countries, five $[29,34,38,39,42]$ from European countries, three [27,35,44] from Oceanian countries, and one [32] was from African countries. Among 24 studies, 21 [27-46] cohort studies or case-control studies were appraised by NOS, resulting with 
scores above 6, while four [47-50] cross-sectional studies were appraised by the ARHQ methodology checklist, which also showed good quality (see supplementary materials).

Most of the studies defined vitamin D deficiency as a serum 25(OH)D below $50 \mathrm{nmol} / \mathrm{L}$ or $20 \mathrm{ng} / \mathrm{mL}$, but two studies [29,42] defined as 25(OH)D below $30 \mathrm{ng} / \mathrm{mL}$ were also included because there were data about serum 25(OH)D below $20 \mathrm{ng} / \mathrm{mL}$; thus, the criteria for diagnosis and data extraction were agreed upon. Similarly, the majority of studies defined preterm birth as a gestational age $<37$ weeks and term birth as a gestational age $\geq 37$ weeks, but one study [46] defining gestational age $<35$ weeks were also included because data about gestational age $<37$ weeks were available.

These studies were carried on from 1999 to 2017, and published from 2012 to 2018. Of 24 studies, seven different assay methods were used to measure maternal vitamin D levels, which is in accordance with the Vitamin D standardization program (VDSP) [51]. Importantly, liquid chromatography tandem mass spectrometry (LC-MS/MS) is considered to be the gold standard for the determination of vitamin $D[51,52]$.

All of these studies described the association between vitamin D deficiency during pregnancy and preterm birth, whether negative or positive.

\subsection{Meta-Analysis}

According to the lower serum 25(OH)D concentration ( $<50 \mathrm{nmol} / \mathrm{L}$ or $<20 \mathrm{ng} / \mathrm{mL}$ ) which diagnosed vitamin $D$ deficiency, the results of the meta-analysis appear to be inconsistent in the different periods of pregnancy. In Figure 2, the association between maternal vitamin $D$ deficiency in the first trimester and preterm birth was not statistically significant $(O R=1.01$, $95 \% \mathrm{Cl}: 0.88,1.16, \mathrm{P}=0.876)$. In Figure 3, the pregnant women with vitamin $\mathrm{D}$ deficiency in the second trimester showed no statistical significance regarding the risk of developing preterm birth $(O R=1.12,95 \% \mathrm{Cl}(0.92,1.37), P=0.249)$ in a random effect model. In Figure 4, the association between maternal vitamin D deficiency in the third trimester and preterm birth was not statistically significant $(\mathrm{OR}=1.05,95 \% \mathrm{Cl}: 0.87,1.27, \mathrm{P}=0.602)$.

\subsection{Sensitivity and Subgroup Analysis}

In the meta-analysis of the association between maternal vitamin D deficiency in the first and third trimesters and preterm birth, tests revealed no heterogeneity $\left(I^{2}=0, P \otimes 0.1 ; I^{2}=15.3 \%, P \otimes 0.1\right)$; thus, a fixed effect model was used for meta-analysis. In the meta-analysis of the relationship between maternal vitamin D deficiency in the second trimester and preterm birth, heterogeneity tests revealed that $\mathrm{I}^{2}=60.3 \%(P<0.1)$, indicative of moderate heterogeneity; thus, a random effect model was used. The sensitivity analyses, shown in Figure 5, indicated significant changes in the result when the study by Zhou et al. [37] was excluded. Subgroup analyses were performed according to the study design and the continents with relevant countries. A significant association was identified in two case-control studies $[40,43]$ between maternal vitamin D deficiency and PTB in Figure $6(\mathrm{OR}=1.33,95 \% \mathrm{Cl}$ : 1.15, 1.54, $\mathrm{P}=0.000)$. Stratifying the countries from different continents in Figure 7 , five studies conducted in Asian countries $[30,31,33,37,40]$ showed high heterogeneity $\left(I^{2}\right.$ $=77.4 \%(P<0.1))$, while the study by Bodnar et al. in the Americas [43] revealed a statistically significant protective effect among pregnant women, with an OR of $1.32(95 \% \mathrm{Cl} 1.13-1.54, \mathrm{P}=0.001)$. A random effect model was used for this metaanalysis because of the heterogeneity in all subgroup analyses.

\subsection{Publication Bias}

The Begg's funnel plot of the effect of vitamin D deficiency in the second trimester on preterm birth appeared to be symmetrical, as shown in Figure 8. No significant publication bias was detected $(P=0.69)$. Regarding other outcomes of vitamin $D$ deficiency in the first or third trimester and preterm birth, due to the limited number of studies, publication biases cannot be excluded.

\section{Discussion}


In this review, 13 of the 24 observational studies clearly reported no effect of vitamin D deficiency during pregnancy on preterm birth, no matter whether in early pregnancy, in middle pregnancy, or in late pregnancy $[27,28,31-33,35,36,39,44-$ $46,48,49]$. However, other studies showed different results. Five of all studies included showed that lower 25(OH)D levels in middle pregnancy are associated with preterm birth, and even that there is a protective association between maternal vitamin D sufficiency and preterm birth $[30,34,38,40,43]$. Kassai et al.'s study shows that mothers who delivered preterm babies had lower 25(OH)D concentrations prior to delivery compared to women who had given birth at the full-term of their pregnancy [47]. Baczyńska-Strzecha et al.'s data confirmed that severe vitamin D deficiency $(<10 \mathrm{ng} / \mathrm{ml})$ in late pregnancy may be a factor increasing the risk of preterm birth [42]. More specially, Zhou et al.'s study showed that preterm birth with a high level of vitamin $\mathrm{D}$ in the second trimester of pregnancy had a higher prevalence than that in low and medium-level groups, possibly related to the older age and higher BMI of the high-level group [37].

There was no observed heterogeneity in studies of vitamin D deficiency and preterm birth in early and late pregnancy, and the results showed there is little association between them. However, moderate heterogeneity existed in the study of the second period of pregnancy, which revealed a positive correlation between vitamin D deficiency and preterm birth. The subgroup of analysis by study design showed two cohort studies $[27,34]$ had a non-ignorable effect. Wilson et al.'s study compared and combined two distinct populations of pregnant women living at similar latitudes, and found that circulating 25(OH)D was different between women recruited in Adelaide compared to women recruited in Auckland [27]. A large-scale prospective cohort including 7098 mothers and their offspring showed lower maternal 25(OH)D concentrations during mid-pregnancy, which were associated with a higher risk of preterm birth, which is different from the majority studies; this may be due to the universality of the study population and the larger sample size, which is likely to be the cause of heterogeneity [34]. Qiu et al.'s study is the main source of heterogeneity [40] in the subgroup of analysis by continents and countries, but there was no heterogeneity shown in the subgroup of analysis by study design. The results of the meta-analysis did not change after removing the papers that caused heterogeneity.

In our meta-analysis, diagnostic criteria of vitamin D deficiency and preterm birth need to be unified first. Vitamin D deficiency is very common all over the world, but it varies by different cut-offs. The American institute of medicine considers a serum level of 25(OH)D above $20 \mathrm{ng} / \mathrm{mL}$ (50 nmol/L) to be sufficient for pregnant women [53], whereas the American endocrine society recommends a serum level of $25(\mathrm{OH}) \mathrm{D}$ above $30 \mathrm{ng} / \mathrm{mL}(75 \mathrm{nmol} / \mathrm{L})$ to be sufficient [54]. Most studies were classified according to the same criteria: vitamin $D$ deficiency $(<20 \mathrm{ng} / \mathrm{mL})$, insufficient $(20-30 \mathrm{ng} / \mathrm{mL})$ and sufficient $(\geq 30 \mathrm{ng} / \mathrm{mL})$. Bärebring et al.'s study [29] and Baczyńska-Strzecha et al.'s study [42] categorized vitamin D deficiency as below $30 \mathrm{ng} / \mathrm{mL}$; the cause for this is perhaps that some European countries were accustomed to use the endocrine society criteria. Luckily, data below $20 \mathrm{ng} / \mathrm{mL}$ were also available, so they were included. Similarly, Baker et al.'s study [39] defined preterm birth as less than 35 weeks, and we could extract data about less than 37 weeks, as with all of the other studies.

Vitamin D levels are usually assessed by measuring the compound 25-hydroxyvitamin $D(25(\mathrm{OH}) \mathrm{D})$, which is the circulating form of vitamin D [55]. According to our statistics, seven assay methods of serum 25(OH)D were used in the 24 studies, including chemiluminescence microparticle immune assay (CMIA), liquid chromatography tandem mass spectrometry (LCMS/MS), radioimmunoassay (RIA), enzyme-linked immunosorbent assay (ELISA), automated immunoassay (AIA), electrochemiluminescence immunoassay (ECLIA), chemiluminescence immunoassay (CLIA). As a fact, there is substantial within-assay variation in 25(OH)D measurement and even greater between-assay variability. The mean inter-assay and intraassay coefficient of variations for serum $25(\mathrm{OH}) \mathrm{D}$ concentration in our 24 studies were about $5 \%$. Such assay variation clearly confounds attempts to define what constitutes the diagnosis of hypovitaminosis D. Therefore, to develop and implement evidence-based clinical guidelines, it is essential that $25(\mathrm{OH}) \mathrm{D}$ measurement be standardized in both clinical and research laboratories; thus, the Vitamin D Standardization Program (VDSP) was born [51]. The VDSP does not mandate or suggest a single analytic approach, but requires researchers to abide by the standardization steps. The above detection methods adopted in our studies basically meet these requirements, and so although the measurement methods are different, the heterogeneity is lower, which provides support for the extrapolation of meta-analysis results. 
As is well known, vitamin $D$ has an important role in maintaining an adequate level of minerals through its influence on calcium and phosphate metabolism for bone mineralization and metabolic functions. The association between vitamin D deficiency and bone diseases such as rickets and osteoporosis is well recognized; however, increasingly, a relationship between vitamin D deficiency and other conditions has been identified [55]. In recent years, studies on vitamin D levels in pregnancy and pregnancy outcomes have become increasingly extensive. The compound $1,25(\mathrm{OH})_{2} \mathrm{D}$ as the active form of vitamin $D$ has non-genomic and genomic effects through its action on vitamin D receptors [56]. The nongenomic effects of vitamin D occur rapidly; examples include protein kinase activation and the activation of ion channels [57]. The genomic effects occur over a long period of time and are mediated by $1,25(\mathrm{OH})_{2} \mathrm{D}$ via the nuclear VDR to initiate and regulate gene expression, which is the engine driving fetal development [58]. Consequently, vitamin D deficiency is associated with increased rates of fetal miscarriage, preeclampsia, gestational diabetes, and impaired fetal and childhood growth and development [56]. On the other hand, vitamin D can also affect the pathophysiology of preterm birth by affecting inflammatory and immunomodulatory processes [59]. It is responsible for initiating the adequate function of toll-like receptors in innate immune responses. Patients with vitamin D deficiency are more susceptible to infection due to the impaired induction of the toll-like antimicrobial peptide cathelicidin in macrophages [60].

As mentioned earlier, several observational studies have drawn different or even opposite conclusions regarding the relationship between vitamin D deficiency and preterm birth. This may be due to differences in the study population, region, ethnicity, etc., and so the results should be interpreted with caution. Some studies excluded from this meta-analysis due to the inclusion and exclusion criteria also illustrate certain conclusions. A large prospective population-based birth cohort study set up in several geographical areas of Spain [61] did not find any evidence of an association of maternal circulating 25(OH)D3 concentration in pregnancy with preterm birth, although there was possible selection bias because they did not measure circulating 25(OH)D2 concentrations, but only the D3 form, which normally makes up the majority (90\%) of 25(OH)D. Rihwa Choi et al.'s data [62] indicated a high prevalence of vitamin D deficiency among pregnant women in Korea, but no significant associations between vitamin D deficiency and preterm birth were observed in the Korean pregnant women. Unfortunately, this study did not specify when the blood was collected to assay 25(OH)D. On the contrary, the study by Megumi Shibata et al. [63] suggested a high prevalence of vitamin D deficiency in perinatal pregnant Japanese women throughout the year, which seems to affect bone metabolism and to be associated with threatened preterm birth. Chandrasekhar Thota et al.'s data [64] from Tennessee, USA showed that in addition to having low levels of serum 25(OH)D, African American women also have lower levels of $1,25-(\mathrm{OH})_{2} \mathrm{D}$ (the active form of vitamin $\mathrm{D}$ ) compared to Caucasian women, and they further revealed that the levels of $1,25-(\mathrm{OH})_{2} \mathrm{D}$ at the time of delivery were significantly lower in women who delivered at preterm compared to their respective term counterparts, for both races. Hence, these results indicated that vitamin D deficiency is a risk factor for PTB in African American and Caucasian women. A meta-analysis of 11 observational studies proved an association between maternal vitamin D levels and preterm birth [10]. In the observational studies, vitamin D concentration was measured in different stages of pregnancy, although not all studies were adjusted for confounders and the definition of preterm birth was not consistent between the studies.

The advantages of our meta-analysis are as follows: firstly, all studies included are middle to high quality, and they were adjusted for their most important factor or any additional factor confounders; secondly, we divided them into the first trimester, the second trimester, and the third trimester of pregnancy by bleeding time, which is also our innovation; thirdly, we unified the diagnostic criteria for vitamin D deficiency and preterm birth; fourthly, in addition to the published literature, we also included some grey papers, such as Master's theses.

The limitation of our study is that although vitamin D supplementation as a case-control was explicitly excluded by our inclusion and exclusion criteria, it was not possible to accurately assess vitamin D intake or whether women in a natural pregnancy took vitamin D supplements on their own during pregnancy. Certainly, vitamin D deficiency in the second trimester was most associated with preterm birth, regardless of whether vitamin D was added in the first trimester.

\section{Conclusions}

Page $7 / 22$ 
Previous studies have concluded that vitamin D deficiency is common worldwide and is associated with many pregnancy outcomes [65]. The relationship between vitamin D deficiency and preterm birth has been widely investigated in recent years. The evidence presented in our meta-analysis suggested that vitamin D deficiency in the second trimester of pregnancy is likely associated with an increased risk of preterm birth, and that there is little correlation between vitamin D deficiency in the first trimester and the third trimester of pregnancy and preterm birth. However, further research should be conducted on vitamin $D$ intake during pregnancy to better determine the risks and benefits associated with such interventions and the potential public health implications.

\section{List Of Abbreviations}

OR: odds ratio; Cl: confidence interval; WHO: World Health Organization; PTB: preterm birth; PRISMA: preferred reporting items for systematic reviews and meta-analyses; AMSTAR: A Measurement Tool to Assess systematic Reviews; NOS: the Newcastle-Ottawa Scale; ARHQ: The Agency for Healthcare Research and Quality; VDSP: the Vitamin D standardization program; LC-MS/MS: liquid chromatography tandem mass spectrometry; CMIA: chemiluminescence microparticle immuno assay; RIA: radioimmunoassay; ELISA: enzyme-linked immunosorbent assay; AIA: automated immunoassay; ECLIA: electrochemiluminescence immunoassay; CLIA: chemiluminescence immunoassay; BMI: body mass index; SEl: socioeconomic index

\section{Supplementary Materials}

S1: Prisma 2009 Checklist, S2: For example: Search strategy used for PubMed-Medline database, S3: Quality assessment of case-control studies by the Newcastle-Ottawa Scale (total of 9 points), S4: Quality assessment of cohort studies by the Newcastle-Ottawa Scale (total of 9 points), S5: Quality assessment of cross-sectional studies by the Agency for Healthcare Research and Quality methodology checklist.

\section{Declarations}

Ethics approval and consent to participate: Not applicable.

Consent for publication: Not applicable.

Availability of data and materials: Identifying/confidential patient data should not be shared.

Competing Interests: The authors declare no conflict of interest.

Funding: This research received no external funding.

Author Contributions: L.R.H., Y.T., and Y.K.H. designed the protocol of the systematic review. L.R.H., Q.P.A, and Y.T. did the literature search, selected studies for inclusion, extracted data for analysis, and performed quality checks. L.R.H. and Q.W.W. performed the statistical analysis and interpreted the data. Y.T., Y.P.J., and Y.K.H. checked the statistical methodology. L.R.H. wrote the first draft, and all authors revised the manuscript for important intellectual content. All authors approved the final draft.

Acknowledgments: Not applicable.

\section{References}

1. WHO: recommended definitions, terminology and format for statistical tables related to the perinatal period and use of a new certificate for cause of perinatal deaths. Modifications recommended by FIGO as amended October 14, 1976. Acta obstetricia et gynecologica Scandinavica 1977, 56, 247-253. 
2. Frey, H.A.; Klebanoff, M.A. The epidemiology, etiology, and costs of preterm birth. Seminars in fetal \& neonatal medicine 2016, 21, 68-73, doi:10.1016/j.siny.2015.12.011.

3. Liu, N.Q.; Kaplan, A.T.; Lagishetty, V.; Ouyang, Y.B.; Ouyang, Y.; Equils, O.; Hewison, M. Vitamin D and the regulation of placental inflammation. Reproductive Sciences 2011, 18, 167A, doi:10.1177/193371912011183s067.

4. Vogel, J.P.; Chawanpaiboon, S.; Moller, A.B.; Watananirun, K.; Bonet, M.; Lumbiganon, P. The global epidemiology of preterm birth. BEST PRACTICE \& RESEARCH CLINICAL OBSTETRICS \& GYNAECOLOGY 2018, 52, 3-12, doi:10.1016/j.bpobgyn.2018.04.003.

5. Platt, M.J. Outcomes in preterm infants. Public Health 2014, 128, 399-403, doi:10.1016/j.puhe.2014.03.010.

6. Martin, J.N.; D’Alton, M.; Jacobsson, B.; Norman, J.E. In Pursuit of Progress Toward Effective Preterm Birth Reduction. Obstetrics and gynecology 2017, 129, 715-719, doi:10.1097/aog.0000000000001923.

7. Salle, B.L.; Delvin, E.E.; Lapillonne, A.; Bishop, N.J.; Glorieux, F.H. Perinatal metabolism of vitamin D. American Society for Clinical Nutrition 2000, 71, 1317s-1324s, doi:10.1093/ajcn/71.5.1317s.

8. Wagner, C.L.; Taylor, S.N.; Dawodu, A.; Johnson, D.D.; Hollis, B.W. Vitamin D and its role during pregnancy in attaining optimal health of mother and fetus. Nutrients 2012, 4, 208-230, doi:10.3390/nu4030208.

9. Agarwal, S.; Kovilam, O.; Agrawal, D.K. Vitamin D and its impact on maternal-fetal outcomes in pregnancy: A critical review. Critical reviews in food science and nutrition 2018, 58, 755-769, doi:10.1080/10408398.2016.1220915.

10. Qin, L.-L.; Lu, F.-G.; Yang, S.-H.; Xu, H.-L.; Luo, B.-A. Does Maternal Vitamin D Deficiency Increase the Risk of Preterm Birth: A Meta-Analysis of Observational Studies. Nutrients 2016, 8, doi:10.3390/nu8050301.

11. Zhou, S.-S.; Tao, Y.-H.; Huang, K.; Zhu, B.-B.; Tao, F.-B. Vitamin D and risk of preterm birth: Up-to-date meta-analysis of randomized controlled trials and observational studies. The journal of obstetrics and gynaecology research 2017,43 , 247-256, doi:10.1111/jog.13239.

12. Tian, J.; Zhang, J.; Ge, L.; Yang, K.; Song, F. The methodological and reporting quality of systematic reviews from China and the USA are similar. J Clin Epidemiol 2017, 85, 50-58, doi:10.1016/j.jclinepi.2016.12.004.

13. Yao, L.; Sun, R.; Chen, Y.L.; Wang, Q.; Wei, D.; Wang, X.; Yang, K. The quality of evidence in Chinese meta-analyses needs to be improved. J Clin Epidemiol 2016, 74, 73-79, doi:10.1016/j.jclinepi.2016.01.003.

14. Moher, D.; Liberati, A.; Tetzlaff, J.; Altman, D.G. Preferred reporting items for systematic reviews and meta-analyses: the PRISMA statement. BMJ (Clinical research ed.) 2009, 339, b2535, doi:10.1136/bmj.b2535.

15. Ge, L.; Tian, J.H.; Li, Y.N.; Pan, J.X.; Li, G.; Wei, D.; Xing, X.; Pan, B.; Chen, Y.L.; Song, F.J., et al. Association between prospective registration and overall reporting and methodological quality of systematic reviews: a meta-epidemiological study. J Clin Epidemiol 2018, 93, 45-55, doi:10.1016/j.jclinepi.2017.10.012.

16. Wang, X.; Chen, Y.; Yao, L.; Zhou, Q.; Wu, Q.; Estill, J.; Wang, Q.; Yang, K.; Norris, S.L. Reporting of declarations and conflicts of interest in WHO guidelines can be further improved. J Clin Epidemiol 2018, 98, 1-8, doi:10.1016/j.jclinepi.2017.12.021.

17. Pieper, D.; Buechter, R.B.; Li, L.; Prediger, B.; Eikermann, M. Systematic review found AMSTAR, but not R(evised)-AMSTAR, to have good measurement properties. J Clin Epidemiol 2015, 68, 574-583, doi:10.1016/j.jclinepi.2014.12.009.

18. Yan, P.; Yao, L.; Li, H.; Zhang, M.; Xun, Y.; Li, M.; Cai, H.; Lu, C.; Hu, L.; Guo, T., et al. The methodological quality of robotic surgical meta-analyses needed to be improved: a cross-sectional study. Journal of Clinical Epidemiology 2019, 109, 2029, doi:https://doi.org/10.1016/j.jclinepi.2018.12.013.

19. O'Connor, D. Defining the Review Question and Developing Criteria for Including Studies, Cochrane Handbook for Systematic Reviews of Interventions: Cochrane Book Series ed.; Wiley, J., Ed. London, UK: Cochrane, 2008.

20. F. Gary Cunningham, K.J.L. Williams OBSTETRICS; New York, USA: The McGraw-Hill Companies, Inc, 2010.

21. Stang, A. Critical evaluation of the Newcastle-Ottawa scale for the assessment of the quality of nonrandomized studies in meta-analyses. European Journal of Epidemiology 2010, 25, 603-605, doi:10.1007/s10654-010-9491-z. 
22. Zhang Simeng, T.P., Xin Fangran, Wei Tingting, He Qiao, Ai Cong, Ni Ping, Shi Jingpu. Cadmium exposure and the risk of hypertension: a meta-analysis. CHINESE JOURNAL OF EVIDENCE-BASED MEDICINE 2018, 18, 1062-1069.

23. Zeng, X.; Zhang, Y.; Kwong, J.S.; Zhang, C.; Li, S.; Sun, F.; Niu, Y.; Du, L. The methodological quality assessment tools for preclinical and clinical studies, systematic review and meta-analysis, and clinical practice guideline: a systematic review. Journal of evidence-based medicine 2015, 8, 2-10, doi:10.1111/jebm.12141.

24. Sanderson, S.; Tatt, I.D.; Higgins, J.P. Tools for assessing quality and susceptibility to bias in observational studies in epidemiology: a systematic review and annotated bibliography. Int J Epidemiol 2007, 36, 666-676, doi:10.1093/ije/dym018.

25. Higgins, J.P.T.; Thompson, S.G. Quantifying heterogeneity in a meta-analysis. Statistics in Medicine 2002, 21, $1539-1558$.

26. Begg, C.B.; Mazumdar, M. Operating characteristics of a rank correlation test for publication bias. Biometrics 1994, 50, 1088-1101.

27. Wilson, R.L.; Leviton, A.J.; Leemaqz, S.Y.; Anderson, P.H.; Grieger, J.A.; Grzeskowiak, L.E.; Verburg, P.E.; McCowan, L.; Dekker, G.A.; Bianco-Miotto, T., et al. Vitamin D levels in an Australian and New Zealand cohort and the association with pregnancy outcome. BMC pregnancy and childbirth 2018, 18, 251-251, doi:10.1186/s12884-018-1887-x.

28. Ding, Y.; Xu, Y.; Wang, Y.; Zhang, Q.; Huang, X.; Tang, Z.; Gu, W.; Fan, J.; Yu, W.; Liu, Z. Vitamin D status in early pregancy. Chinese Journal of Clinical Nutrition 2018, 26, 278-283, doi:10.3760/cma.j.issn.1674-635X.2018.05.004.

29. Bärebring, L.; Bullarbo, M.; Glantz, A.; Hulthén, L.; Ellis, J.; Jagner, Å.; Schoenmakers, I.; Winkvist, A.; Augustin, H. Trajectory of vitamin $D$ status during pregnancy in relation to neonatal birth size and fetal survival: a prospective cohort study. BMC pregnancy and childbirth 2018, 18, 51-51, doi:10.1186/s12884-018-1683-7.

30. Shanshan, Z. Maternal Vitamin D Status at Three Time Points during Pregnancy and Preterm Birth: A Population-based Birth Cohort Study. Master, Anhui Medical University, 2017.

31. Jinhuan, C. Associations between 25-hydroxyvitamin D levels and pregnancy outcomes. Master, Fujian Medical University, 2017.

32. Toko, E.N.; Sumba, O.P.; Daud, II; Ogolla, S.; Majiwa, M.; Krisher, J.T.; Ouma, C.; Dent, A.E.; Rochford, R.; Mehta, S. Maternal Vitamin D Status and Adverse Birth Outcomes in Children from Rural Western Kenya. Nutrients 2016, 8, doi:10.3390/nu8120794.

33. Ong, Y.L.; Quah, P.L.; Tint, M.T.; Aris, I.M.; Chen, L.W.; van Dam, R.M.; Heppe, D.; Saw, S.-M.; Godfrey, K.M.; Gluckman, P.D., et al. The association of maternal vitamin D status with infant birth outcomes, postnatal growth and adiposity in the first 2 years of life in a multi-ethnic Asian population: the Growing Up in Singapore Towards healthy Outcomes (GUSTO) cohort study. The British journal of nutrition 2016, 116, 621-631, doi:10.1017/S0007114516000623.

34. Miliku, K.; Vinkhuyzen, A.; Blanken, L.M.; McGrath, J.J.; Eyles, D.W.; Burne, T.H.; Hofman, A.; Tiemeier, H.; Steegers, E.A.; Gaillard, R., et al. Maternal vitamin D concentrations during pregnancy, fetal growth patterns, and risks of adverse birth outcomes. The American journal of clinical nutrition 2016, 103, 1514-1522, doi:10.3945/ajcn.115.123752.

35. Boyle, V.T.; Thorstensen, E.B.; Mourath, D.; Jones, M.B.; McCowan, L.M.E.; Kenny, L.C.; Baker, P.N. The relationship between 25-hydroxyvitamin $D$ concentration in early pregnancy and pregnancy outcomes in a large, prospective cohort. The British journal of nutrition 2016, 116, 1409-1415.

36. Flood-Nichols, S.K.; Tinnemore, D.; Huang, R.R.; Napolitano, P.G.; Ippolito, D.L. Vitamin D deficiency in early pregnancy. PLoS ONE 2015, 10, doi:10.1371/journal.pone.0123763.

37. Zhou, J.; Su, L.; Liu, M.; Liu, Y.; Cao, X.; Wang, Z.; Xiao, H. Associations between 25-hydroxyvitamin D levels and pregnancy outcomes: a prospective observational study in southern China. European Journal Of Clinical Nutrition 2014, 68, 925-930, doi:10.1038/ejcn.2014.99.

38. Perez-Ferre, N.; Torrejon, M.J.; Fuentes, M.; Fernandez, M.D.; Ramos, A.; Bordiu, E.; del Valle, L.; Rubio, M.A.; Bedia, A.R.; Montañez, C., et al. Association of low serum 25-hydroxyvitamin D levels in pregnancy with glucose homeostasis and obstetric and newborn outcomes. Endocrine Practice 2012, 18, 676-684, doi:10.4158/EP12025.0R. 
39. Fernández-Alonso, A.M.; Dionis-Sánchez, E.C.; Chedraui, P.; González-Salmerón, M.D.; Pérez-López, F.R. First-trimester maternal serum 25-hydroxyvitamin $\mathrm{D} \otimes$ status and pregnancy outcome. International Journal of Gynecology and Obstetrics 2012, 116, 6-9, doi:10.1016/j.ijgo.2011.07.029.

40. Qiu Haifan; Wang Jianping; Wang Rongyue; Wang Fan; Wang Ledan; Xie Ailan. Effect of serum 25- hydroxyvitamin D level on perinatal outcome during pregnancy. Zhejiang Medical 2018, 40, 1062-1063,1077.

41. Tabatabaei, N.; Auger, N.; Herba, C.M.; Wei, S.; Allard, C.; Fink, G.D.; Fraser, W.D. Maternal Vitamin D Insufficiency Early in Pregnancy Is Associated with Increased Risk of Preterm Birth in Ethnic Minority Women in Canada. The Journal of nutrition 2017, 147, 1145-1151, doi:10.3945/jn.116.241216.

42. Baczyńska-Strzecha, M.; Kalinka, J. Assessment of correlation between vitamin D level and prevalence of preterm births in the population of pregnant women in Poland. International journal of occupational medicine and environmental health 2017, 30, 933-941, doi:10.13075/ijomeh.1896.01146.

43. Bodnar, L.M.; Platt, R.W.; Simhan, H.N. Early-pregnancy vitamin D deficiency and risk of preterm birth subtypes. Obstetrics and gynecology 2015, 125, 439-447, doi:10.1097/AOG.0000000000000621.

44. Schneuer, F.J.; Roberts, C.L.; Guilbert, C.; Simpson, J.M.; Algert, C.S.; Khambalia, A.Z.; Tasevski, V.; Ashton, A.W.; Morris, J.M.; Nassar, N. Effects of maternal serum 25-hydroxyvitamin D concentrations in the first trimester on subsequent pregnancy outcomes in an Australian population. The American journal of clinical nutrition 2014, 99, 287-295, doi:10.3945/ajcn.113.065672.

45. Dunlop, A.L.; Taylor, R.N.; Tangpricha, V.; Fortunato, S.; Menon, R. Maternal micronutrient status and preterm versus term birth for black and white US women. Reproductive sciences 2012, 19, 939-948, doi:10.1177/1933719112438442.

46. Baker, A.M.; Haeri, S.; Camargo, C.A., Jr.; Stuebe, A.M.; Boggess, K.A. A nested case-control study of first-trimester maternal vitamin D status and risk for spontaneous preterm birth. American journal of perinatology 2011, 28, 667-672, doi:10.1055/s-0031-1276731.

47. Kassai, M.S.; Cafeo, F.R.; Affonso-Kaufman, F.A.; Suano-Souza, F.I.; Sarni, R.O.S. Vitamin D plasma concentrations in pregnant women and their preterm newborns. BMC pregnancy and childbirth 2018, 18, doi:10.1186/s12884-018-2045-1.

48. Bhupornvivat, N.; Phupong, V. Serum 25-hydroxyvitamin D in pregnant women during preterm labor. Asia Pacific journal of clinical nutrition 2017, 26, 287-290, doi:10.6133/apjcn.112015.11.

49. Yue, W. Associations between maternal vitamin D levels and preterm birth. Master, Kunming Medical University, 2015.

50. Zhu, T.; Liu, T.-J.; Ge, X.; Kong, J.; Zhang, L.-J.; Zhao, Q. High prevalence of maternal vitamin D deficiency in preterm births in northeast China, Shenyang. International journal of clinical and experimental pathology 2015, 8, 1459-1465.

51. Binkley, N.; Sempos, C.T. Standardizing vitamin D assays: the way forward. Journal of Bone and Mineral Research 2014, 29, 1709-1714, doi:10.1002/jbmr.2252.

52. Granado Lorencio, F.; Blanco-Navarro, l.; Pérez-Sacrsitán, B. Critical evaluation of assays for vitamin D status. Current opinion in clinical nutrition and metabolic care 2013, 16, 734-740, doi:10.1097/MC0.0b013e328364ca96.

53. Ross, A.C.; Manson, J.E.; Abrams, S.A.; Aloia, J.F.; Brannon, P.M.; Clinton, S.K.; Durazo-Arvizu, R.A.; Gallagher, J.C.; Gallo, R.L.; Jones, G., et al. The 2011 report on dietary reference intakes for calcium and vitamin $D$ from the Institute of Medicine: what clinicians need to know. The Journal of Clinical Endocrinology \& Metabolism 2011, 96, 53-58, doi:10.1210/jc.2010-2704.

54. Holick, M.F.; Binkley, N.C.; Bischoff-Ferrari, H.A.; Gordon, C.M.; Hanley, D.A.; Heaney, R.P.; Murad, M.H.; Weaver, C.M. Evaluation, treatment, and prevention of vitamin D deficiency: an Endocrine Society clinical practice guideline. The Journal of Clinical Endocrinology \& Metabolism 2011, 96, 1911-1930, doi:10.1210/jc.2011-0385.

55. Sahota, O. Understanding vitamin D deficiency. Age and ageing 2014, 43, 589-591, doi:10.1093/ageing/afu104.

56. Heyden, E.L.; Wimalawansa, S.J. Vitamin D: Effects on human reproduction, pregnancy, and fetal well-being. Journal of Steroid Biochemistry and Molecular Biology 2018, 180, 41-50, doi:10.1016/j.jsbmb.2017.12.011.

57. Bikle, Daniel D. Vitamin D Metabolism, Mechanism of Action, and Clinical Applications. Chemistry \& Biology 2014, 21, 319-329, doi:https://doi.org/10.1016/j.chembiol.2013.12.016.

Page $11 / 22$ 
58. Schulz, E.V.; Cruze, L.; Wei, W.; Gehris, J.; Wagner, C.L. Maternal vitamin D sufficiency and reduced placental gene expression in angiogenic biomarkers related to comorbidities of pregnancy. The Journal of steroid biochemistry and molecular biology 2017, 173, 273-279, doi:https://doi.org/10.1016/j.jsbmb.2017.02.003.

59. Dovnik, A.; Mujezinović, F. The association of vitamin D levels with common pregnancy complications. Nutrients 2018 , 10, doi:10.3390/nu10070867.

60. Bodnar, L.M.; Klebanoff, M.A.; Gernand, A.D.; Platt, R.W.; Parks, W.T.; Catov, J.M.; Simhan, H.N. Maternal vitamin D status and spontaneous preterm birth by placental histology in the US Collaborative Perinatal Project. Am. J. Epidemiol. 2014, 179, 168-176, doi:10.1093/aje/kwt237.

61. Rodriguez, A.; García-Esteban, R.; Basterretxea, M.; Lertxundi, A.; Rodríguez-Bernal, C.; Iñiguez, C.; Rodriguez-Dehli, C.; Tardón, A.; Espada, M.; Sunyer, J., et al. Associations of maternal circulating 25-hydroxyvitamin D3 concentration with pregnancy and birth outcomes. BJOG: An International Journal Of Obstetrics And Gynaecology 2015, 122, 1695-1704, doi:10.1111/1471-0528.13074.

62. Choi, R.; Kim, S.; Yoo, H.; Cho, Y.Y.; Kim, S.W.; Chung, J.H.; Oh, S.-y.; Lee, S.-Y. High prevalence of vitamin D deficiency in pregnant Korean women: the first trimester and the winter season as risk factors for vitamin D deficiency. Nutrients 2015 , 7, 3427-3448, doi:10.3390/nu7053427.

63. Shibata, M.; Suzuki, A.; Sekiya, T.; Sekiguchi, S.; Asano, S.; Udagawa, Y.; Itoh, M. High prevalence of hypovitaminosis D in pregnant Japanese women with threatened premature delivery. Journal of Bone and Mineral Metabolism 2011, 29, 615620, doi:10.1007/s00774-011-0264-x.

64. Thota, C.; Menon, R.; Fortunato, S.J.; Brou, L.; Lee, J.-E.; Al-Hendy, A. 1,25-Dihydroxyvitamin D deficiency is associated with preterm birth in African American and Caucasian women. Reproductive sciences (Thousand Oaks, Calif.) 2014, 21, 244-250, doi:10.1177/1933719113493513.

65. Olmos-Ortiz, A.; Avila, E.; Durand-Carbajal, M.; Díaz, L. Regulation of calcitriol biosynthesis and activity: Focus on gestational vitamin D deficiency and adverse pregnancy outcomes. Nutrients 2015, 7, 443-480, doi:10.3390/nu7010443.

\section{Table}


Table 1. Characteristics of studies included in the meta-analysis. PTB: preterm birth.

\begin{tabular}{|c|c|c|c|c|c|c|c|c|c|}
\hline $\begin{array}{c}\text { First } \\
\text { author's last } \\
\text { name(year) }\end{array}$ & $\begin{array}{c}\text { Country } \\
\text { (province or } \\
\text { city) of study }\end{array}$ & $\begin{array}{c}\text { Study } \\
\text { design }\end{array}$ & Time & Age & $\begin{array}{l}\text { Gestational } \\
\text { age at } \\
\text { serum } \\
\text { sampling }\end{array}$ & $\begin{array}{c}\text { Assay } \\
\text { method } \\
\text { of serum } \\
25(\mathrm{OH}) \mathrm{D}\end{array}$ & $\begin{array}{l}\text { Diagnostic } \\
\text { criteria of } \\
\text { vitamin D } \\
\text { deficiency }\end{array}$ & $\begin{array}{c}\text { Diagnostic } \\
\text { criteria of } \\
\text { PTB }\end{array}$ & Adjustment \\
\hline $\begin{array}{c}\text { Ding (2018) } \\
{[28]}\end{array}$ & $\begin{array}{c}\text { China } \\
\text { (Shanghai) }\end{array}$ & $\begin{array}{l}\text { cohort } \\
\text { study }\end{array}$ & $\begin{array}{l}2015.1- \\
2016.12\end{array}$ & $31 \pm 3.5$ & $\leq 90$ days & CMIA & $\begin{array}{c}25(\mathrm{OH}) \mathrm{D} \\
<50 \\
\mathrm{nmol} / \mathrm{L}\end{array}$ & $\begin{array}{c}<37 \\
\text { weeks }\end{array}$ & $a, b, c$ \\
\hline $\begin{array}{l}\text { Bärebring } \\
\text { (2018) [29] }\end{array}$ & $\begin{array}{c}\text { Sweden } \\
\text { (Gothenburg) }\end{array}$ & $\begin{array}{l}\text { cohort } \\
\text { study }\end{array}$ & $\begin{array}{l}\text { fall, } 2013 \\
\text { to spring, } \\
2014\end{array}$ & $\begin{array}{c}\text { not } \\
\text { mentioned }\end{array}$ & $\begin{array}{c}\text { 8-12 } \\
\text { weeks } 32- \\
\text { 35 weeks }\end{array}$ & $\begin{array}{l}\text { LC- } \\
\text { MS/MS }\end{array}$ & $\begin{array}{c}25(\mathrm{OH}) \mathrm{D} \\
<30 \\
\mathrm{nmol} / \mathrm{L}\end{array}$ & $\begin{array}{c}<37 \\
\text { weeks }\end{array}$ & $c, e, f, g$ \\
\hline $\begin{array}{c}\text { Zhou (2017) } \\
{[30]}\end{array}$ & $\begin{array}{l}\text { China (Ma an- } \\
\text { shan) }\end{array}$ & $\begin{array}{l}\text { cohort } \\
\text { study }\end{array}$ & $\begin{array}{l}2013.5- \\
2014.9\end{array}$ & $26.1 \pm 3.7$ & $\begin{array}{c}<14 \text { weeks } \square \\
24-28 \\
\text { weeks } \square>32 \\
\text { weeks }\end{array}$ & RIA & $\begin{array}{c}25(\mathrm{OH}) \mathrm{D} \\
<20 \\
\mathrm{ng} / \mathrm{mL}\end{array}$ & $\begin{array}{c}28-36+6 \\
\text { weeks }\end{array}$ & $\begin{array}{c}a, b, e, g \\
h, i, j, k\end{array}$ \\
\hline $\begin{array}{c}\text { Chen (2017) } \\
\text { [31] }\end{array}$ & China (Fujian) & $\begin{array}{l}\text { cohort } \\
\text { study }\end{array}$ & $\begin{array}{l}2015.10 .1- \\
2016.9 .30\end{array}$ & $\begin{array}{l}29.09 \pm \\
4.33\end{array}$ & $\begin{array}{c}<13 \text { weeks } \square \\
24-28 \\
\text { weeks } 32- \\
34 \text { weeks }\end{array}$ & $\begin{array}{l}\text { LC- } \\
\mathrm{MS} / \mathrm{MS}\end{array}$ & $\begin{array}{c}25(\mathrm{OH}) \mathrm{D} \\
\leq 20 \\
\mathrm{ng} / \mathrm{mL}\end{array}$ & $\begin{array}{c}<37 \\
\text { weeks }\end{array}$ & $\mathrm{a}, \mathrm{l}, \mathrm{m}$ \\
\hline $\begin{array}{l}\text { Tabatabaei } \\
\text { (2017) [41] }\end{array}$ & $\begin{array}{l}\text { Canada } \\
\text { (Quebec) }\end{array}$ & $\begin{array}{l}\text { case- } \\
\text { control } \\
\text { study }\end{array}$ & $\begin{array}{c}\text { not } \\
\text { mentioned }\end{array}$ & $\begin{array}{c}\text { aged } \geq 18 \\
y\end{array}$ & 8-14 weeks & $\begin{array}{l}\text { LC- } \\
\text { MS/MS }\end{array}$ & $\begin{array}{c}25(\mathrm{OH}) \mathrm{D} \\
<50 \\
\mathrm{nmol} / \mathrm{L}\end{array}$ & $\begin{array}{c}<37 \\
\text { weeks }\end{array}$ & $\begin{array}{c}a, b, c, d, f, \\
\text { i, m }\end{array}$ \\
\hline $\begin{array}{c}\text { Flood- } \\
\text { Nichols } \\
\text { (2015) [36] }\end{array}$ & $\begin{array}{c}\text { USA } \\
\text { (Madigan) }\end{array}$ & $\begin{array}{l}\text { cohort } \\
\text { study }\end{array}$ & 2014 & $24.3 \pm 4.4$ & 5-12 weeks & ELISA & $\begin{array}{c}25(\mathrm{OH}) \mathrm{D} \\
<50 \\
\mathrm{nmol} / \mathrm{L}\end{array}$ & $\begin{array}{c}<37 \\
\text { weeks }\end{array}$ & $b, c, d, f$ \\
\hline $\begin{array}{l}\text { Schneuer } \\
(2014)[44]\end{array}$ & $\begin{array}{l}\text { Australia } \\
\text { (New South } \\
\text { Wales) }\end{array}$ & $\begin{array}{l}\text { case- } \\
\text { control } \\
\text { study }\end{array}$ & $\begin{array}{l}2006.10- \\
2007.9\end{array}$ & $33.1 \pm 4.7$ & $\begin{array}{l}10-14 \\
\text { weeks }\end{array}$ & AIA & $\begin{array}{c}25(\mathrm{OH}) \mathrm{D} \\
<50 \\
\mathrm{nmol} / \mathrm{L}\end{array}$ & $\begin{array}{c}<37 \\
\text { weeks }\end{array}$ & $\begin{array}{c}a, b, c, e, f, \\
i, m\end{array}$ \\
\hline $\begin{array}{l}\text { Fernández- } \\
\text { Alonso } \\
\text { (2012) [39] }\end{array}$ & $\begin{array}{c}\text { Spain } \\
\text { (Almería) }\end{array}$ & $\begin{array}{l}\text { cohort } \\
\text { study }\end{array}$ & $\begin{array}{l}2009.5 .1- \\
2010.4 .30\end{array}$ & $\begin{array}{c}\text { not } \\
\text { mentioned }\end{array}$ & $\begin{array}{r}11-14 \\
\text { weeks }\end{array}$ & ECLIA & $\begin{array}{c}25(\mathrm{OH}) \mathrm{D} \\
\leq 20 \\
\mathrm{ng} / \mathrm{mL}\end{array}$ & $\begin{array}{c}<37 \\
\text { weeks }\end{array}$ & $b, c, d, f$ \\
\hline $\begin{array}{c}\text { Baker } \\
\text { (2011) [46] }\end{array}$ & $\begin{array}{l}\text { USA (North } \\
\text { Carolina) }\end{array}$ & $\begin{array}{l}\text { case- } \\
\text { control } \\
\text { study }\end{array}$ & $\begin{array}{l}2004.11- \\
2009.7\end{array}$ & $\begin{array}{c}33.5 \pm \\
1.75\end{array}$ & $\begin{array}{l}11-14 \\
\text { weeks }\end{array}$ & $\begin{array}{c}\mathrm{LC}- \\
\mathrm{MS} / \mathrm{MS}\end{array}$ & $\begin{array}{c}25(\mathrm{OH}) \mathrm{D} \\
<50 \\
\mathrm{nmol} / \mathrm{L}\end{array}$ & $\begin{array}{l}230 / 7-34 \\
6 / 7 \text { weeks }\end{array}$ & $\mathrm{a}, \mathrm{b}, \mathrm{c}, \mathrm{n}$ \\
\hline $\begin{array}{l}\text { Qiu (2018) } \\
\text { [40] }\end{array}$ & $\begin{array}{c}\text { China } \\
\text { (Wenzhou) }\end{array}$ & $\begin{array}{l}\text { case- } \\
\text { control } \\
\text { study }\end{array}$ & 2016.6-9 & $\begin{array}{l}28.75 \pm \\
4.25\end{array}$ & $\begin{array}{l}\text { about } 20 \\
\text { weeks }\end{array}$ & ECLIA & $\begin{array}{c}25(\mathrm{OH}) \mathrm{D} \\
<50 \\
\mathrm{nmol} / \mathrm{L}\end{array}$ & $\begin{array}{c}\quad<37 \\
\text { weeks }\end{array}$ & $\mathrm{a}, \mathrm{b}, \mathrm{m}$ \\
\hline $\begin{array}{c}\text { Wilson } \\
\text { (2018) [27] }\end{array}$ & $\begin{array}{l}\text { Australian } \\
\text { (Adelaide) and } \\
\text { New Zealand } \\
\text { (Auckland) }\end{array}$ & $\begin{array}{l}\text { cohort } \\
\text { study }\end{array}$ & $\begin{array}{l}2004.11- \\
2008.9\end{array}$ & $28 \pm 6$ & $\begin{array}{l}15 \pm 1 \\
\text { weeks }\end{array}$ & CLIA & $\begin{array}{c}25(\mathrm{OH}) \mathrm{D} \\
<50 \\
\mathrm{nmol} / \mathrm{L}\end{array}$ & $\begin{array}{c}\leq 37 \\
\text { weeks }\end{array}$ & $\begin{array}{c}a, b, c, d, f, \\
i, j, p\end{array}$ \\
\hline $\begin{array}{c}\text { Toko (2016) } \\
{[32]}\end{array}$ & $\begin{array}{c}\text { Kenya } \\
\text { (Kisumu) }\end{array}$ & $\begin{array}{l}\text { cohort } \\
\text { study }\end{array}$ & $\begin{array}{l}2011.6- \\
2012.7\end{array}$ & $22.5 \pm 6.6$ & $\begin{array}{l}19.9 \pm 5.7 \\
\text { weeks }\end{array}$ & ELISA & $\begin{array}{c}25(\mathrm{OH}) \mathrm{D} \\
<50 \\
\mathrm{nmol} / \mathrm{L}\end{array}$ & $\begin{array}{c}<37 \\
\text { weeks }\end{array}$ & $\mathrm{a}, \mathrm{b}$ \\
\hline $\begin{array}{c}\text { Ong (2016) } \\
{[33]}\end{array}$ & Singapore & $\begin{array}{l}\text { cohort } \\
\text { study }\end{array}$ & $\begin{array}{l}2009.6- \\
2010.9\end{array}$ & $30.5 \pm 5.1$ & $\begin{array}{r}26-28 \\
\text { weeks }\end{array}$ & $\begin{array}{c}\text { LC- } \\
\text { MS/MS }\end{array}$ & $\begin{array}{c}25(\mathrm{OH}) \mathrm{D} \\
<50 \\
\mathrm{nmol} / \mathrm{L}\end{array}$ & $\begin{array}{c}<37 \\
\text { weeks }\end{array}$ & $\begin{array}{c}a, b, d, f, h, \\
k, q\end{array}$ \\
\hline $\begin{array}{c}\text { Miliku } \\
\text { (2016) [34] }\end{array}$ & $\begin{array}{l}\text { Netherlands } \\
\text { (Rotterdam) }\end{array}$ & $\begin{array}{l}\text { cohort } \\
\text { study }\end{array}$ & $\begin{array}{l}2002.4- \\
2006.1\end{array}$ & $29.7 \pm 5.2$ & $\begin{array}{l}18.5-23.3 \\
\text { weeks }\end{array}$ & $\begin{array}{c}\text { LC- } \\
\text { MS/MS }\end{array}$ & $\begin{array}{c}25(\mathrm{OH}) \mathrm{D} \\
<50 \\
\mathrm{nmol} / \mathrm{L}\end{array}$ & $\begin{array}{c}<37 \\
\text { weeks }\end{array}$ & $\begin{array}{c}a, b, c, d, f \\
g, h, j, m, \\
q, r, s\end{array}$ \\
\hline $\begin{array}{c}\text { Boyle (2016) } \\
{[35]}\end{array}$ & $\begin{array}{l}\text { New Zealand } \\
\text { (Auckland) }\end{array}$ & $\begin{array}{l}\text { cohort } \\
\text { study }\end{array}$ & $2005-2008$ & $30.3 \pm 4.7$ & 15 weeks & $\begin{array}{c}\text { LC- } \\
\text { MS/MS }\end{array}$ & $\begin{array}{c}25(\mathrm{OH}) \mathrm{D} \\
<50 \\
\mathrm{nmol} / \mathrm{L}\end{array}$ & $\begin{array}{c}<37 \\
\text { weeks }\end{array}$ & $b, d$ \\
\hline $\begin{array}{l}\text { Bodnar } \\
\text { (2015) [43] }\end{array}$ & $\begin{array}{c}\text { USA } \\
\text { (Pittsburgh) }\end{array}$ & $\begin{array}{c}\text { case- } \\
\text { control }\end{array}$ & $\begin{array}{l}\text { 1999- } \\
2001,\end{array}$ & $\begin{array}{c}\text { not } \\
\text { mentioned }\end{array}$ & 20 weeks & $\begin{array}{c}\text { LC- } \\
\text { MS/MS }\end{array}$ & $\begin{array}{l}25(\mathrm{OH}) \mathrm{D} \\
<50\end{array}$ & $\begin{array}{c}<37 \\
\text { weeks }\end{array}$ & $\begin{array}{c}\text { b, c, d, f, h, } \\
\text { m, u }\end{array}$ \\
\hline
\end{tabular}




\begin{tabular}{|c|c|c|c|c|c|c|c|c|c|}
\hline & & study & $\begin{array}{c}\text { 2003, } \\
2007-2010\end{array}$ & & & & $\mathrm{nmol} / \mathrm{L}$ & & \\
\hline $\begin{array}{c}\text { Zhou (2014) } \\
{[37]}\end{array}$ & $\begin{array}{c}\text { China } \\
\text { (Guangzhou) }\end{array}$ & $\begin{array}{l}\text { cohort } \\
\text { study }\end{array}$ & $\begin{array}{l}2010.9- \\
2011.8\end{array}$ & $\geqslant 18$ years & $\begin{array}{l}16-20 \\
\text { weeks }\end{array}$ & ECLIA & $\begin{array}{c}25(\mathrm{OH}) \mathrm{D} \\
<20 \\
\mathrm{ng} / \mathrm{mL}\end{array}$ & $\begin{array}{c}<37 \\
\text { weeks }\end{array}$ & $a, b, o, z$ \\
\hline $\begin{array}{c}\text { Perez-Ferre } \\
\text { (2012) [38] }\end{array}$ & $\begin{array}{l}\text { Spain } \\
\text { (Madrid) }\end{array}$ & $\begin{array}{l}\text { cohort } \\
\text { study }\end{array}$ & $\begin{array}{l}2010.6 .1- \\
9.30\end{array}$ & $\begin{array}{c}32.5 \pm \\
1.75\end{array}$ & $\begin{array}{l}24-28 \\
\text { weeks }\end{array}$ & CLIA & $\begin{array}{c}25(\mathrm{OH}) \mathrm{D} \\
<20 \\
\mathrm{ng} / \mathrm{mL}\end{array}$ & $\begin{array}{c}<37 \\
\text { weeks }\end{array}$ & $a, b, d, f, y$ \\
\hline $\begin{array}{c}\text { Kassai } \\
\text { (2018) [47] }\end{array}$ & $\begin{array}{l}\text { Brazil (São } \\
\text { Paulo) }\end{array}$ & $\begin{array}{l}\text { cross- } \\
\text { sectional } \\
\text { study }\end{array}$ & $\begin{array}{l}2016.3- \\
2017.5\end{array}$ & $26.0 \pm 7.3$ & $\begin{array}{c}\text { at the time } \\
\text { of the } \\
\text { delivery } \\
\text { admission }\end{array}$ & ECLIA & $\begin{array}{c}25(\mathrm{OH}) \mathrm{D} \\
<20 \\
\mathrm{ng} / \mathrm{mL}\end{array}$ & $\begin{array}{c}<37 \\
\text { weeks }\end{array}$ & $\begin{array}{c}a, b, d, f, g \\
m, j, x\end{array}$ \\
\hline $\begin{array}{c}\text { Bhupornvivat } \\
\text { (2017) [48] }\end{array}$ & $\begin{array}{l}\text { Thailand } \\
\text { (Bangkok) }\end{array}$ & $\begin{array}{l}\text { cross- } \\
\text { sectional } \\
\text { study }\end{array}$ & $\begin{array}{l}\text { 2014.7.1- } \\
2015.5 .31\end{array}$ & $28.9 \pm 7.6$ & $\begin{array}{l}\text { prior to } \\
\text { labor }\end{array}$ & ECLIA & $\begin{array}{c}25(\mathrm{OH}) \mathrm{D} \\
<20 \\
\mathrm{ng} / \mathrm{mL}\end{array}$ & $\begin{array}{c}\quad<37 \\
\text { weeks }\end{array}$ & $\mathrm{a}, \mathrm{b}, \mathrm{d}, \mathrm{l}$ \\
\hline $\begin{array}{l}\text { Baczyńska- } \\
\text { Strzecha } \\
\text { (2017) [42] }\end{array}$ & Poland (Lodz) & $\begin{array}{l}\text { case- } \\
\text { control } \\
\text { study }\end{array}$ & 2013-2015 & $\begin{array}{l}30.5 \pm \\
5.75\end{array}$ & $\begin{array}{l}\text { prior to } \\
\text { labor }\end{array}$ & ELISA & $\begin{array}{c}25(\mathrm{OH}) \mathrm{D} \\
<30 \\
\mathrm{ng} / \mathrm{mL}\end{array}$ & $\begin{array}{l}22-36.6 \\
\text { weeks }\end{array}$ & $a, b, v, w$ \\
\hline $\begin{array}{c}\text { Wang (2015) } \\
\text { [49] }\end{array}$ & $\begin{array}{c}\text { China } \\
\text { (Kunming) }\end{array}$ & $\begin{array}{l}\text { cross- } \\
\text { sectional } \\
\text { study }\end{array}$ & 2014.5-11 & $28.9 \pm 7$ & $\begin{array}{l}\text { prior to } \\
\text { labor }\end{array}$ & $\begin{array}{c}\text { LC- } \\
\text { MS/MS }\end{array}$ & $\begin{array}{c}25(\mathrm{OH}) \mathrm{D} \\
<20 \\
\mathrm{ng} / \mathrm{mL}\end{array}$ & $\begin{array}{c}<37 \\
\text { weeks }\end{array}$ & $\mathrm{d}, \mathrm{g}, \mathrm{h}, \mathrm{t}$ \\
\hline $\begin{array}{c}\text { Zhu (2015) } \\
{[50]}\end{array}$ & $\begin{array}{c}\text { China } \\
\text { (Shenyang) }\end{array}$ & $\begin{array}{l}\text { cross- } \\
\text { sectional } \\
\text { study }\end{array}$ & $\begin{array}{l}\text { 2012.1.1- } \\
2013.1 .1\end{array}$ & $31 \pm 7$ & $\begin{array}{l}\text { prior to } \\
\text { labor }\end{array}$ & ELISA & $\begin{array}{c}25(\mathrm{OH}) \mathrm{D} \\
<50 \\
\mathrm{nmol} / \mathrm{L}\end{array}$ & $\begin{array}{c}\quad<37 \\
\text { weeks }\end{array}$ & $\mathrm{C}$ \\
\hline $\begin{array}{c}\text { Dunlop } \\
\text { (2012) [45] }\end{array}$ & $\begin{array}{c}\text { USA } \\
\text { (Nashville) }\end{array}$ & $\begin{array}{l}\text { case- } \\
\text { control } \\
\text { study }\end{array}$ & $2003-2006$ & $\begin{array}{c}25.95 \pm \\
6.0\end{array}$ & $\begin{array}{c}\text { at the time } \\
\text { of the } \\
\text { delivery } \\
\text { admission }\end{array}$ & ELISA & $\begin{array}{c}25(\mathrm{OH}) \mathrm{D} \\
<20 \\
\mathrm{ng} / \mathrm{mL}\end{array}$ & $\begin{array}{l}220 / 7-36 \\
6 / 7 \text { weeks }\end{array}$ & $a, b, d, n, u$ \\
\hline
\end{tabular}

CMIA: chemiluminescence microparticle immuno assay; LC-MS/MS: liquid chromatography tandem mass spectrometry; RIA: radioimmunoassay; ELISA: enzyme-linked immunosorbent assay; AIA: automated immunoassay; ECLIA: electrochemiluminescence immunoassay; CLIA: chemiluminescence immunoassay; a: maternal age; b: BMI, body mass index; c: season; d: ethnicity; e: residence; f: tobacco use; g: vitamin D supplementation; h: educational level; i: family income or SEI, socioeconomic index; j: alcohol consumption; k: gender of the fetus; l: gravidity; m: parity; n: insurance status; o: serum calcium; p: recreational walking; q: total maternal energy intake; $r$ : gestational hypertensive disorders; $s$ : gestational diabetes; t: duration of sunshine during pregnancy; $u$ : marital status; v: vocational activity; w: living conditions; $\mathrm{x}$ :sunscreen use; y: family and personal history; z:systolic/diastolic pressure

\section{Figures}




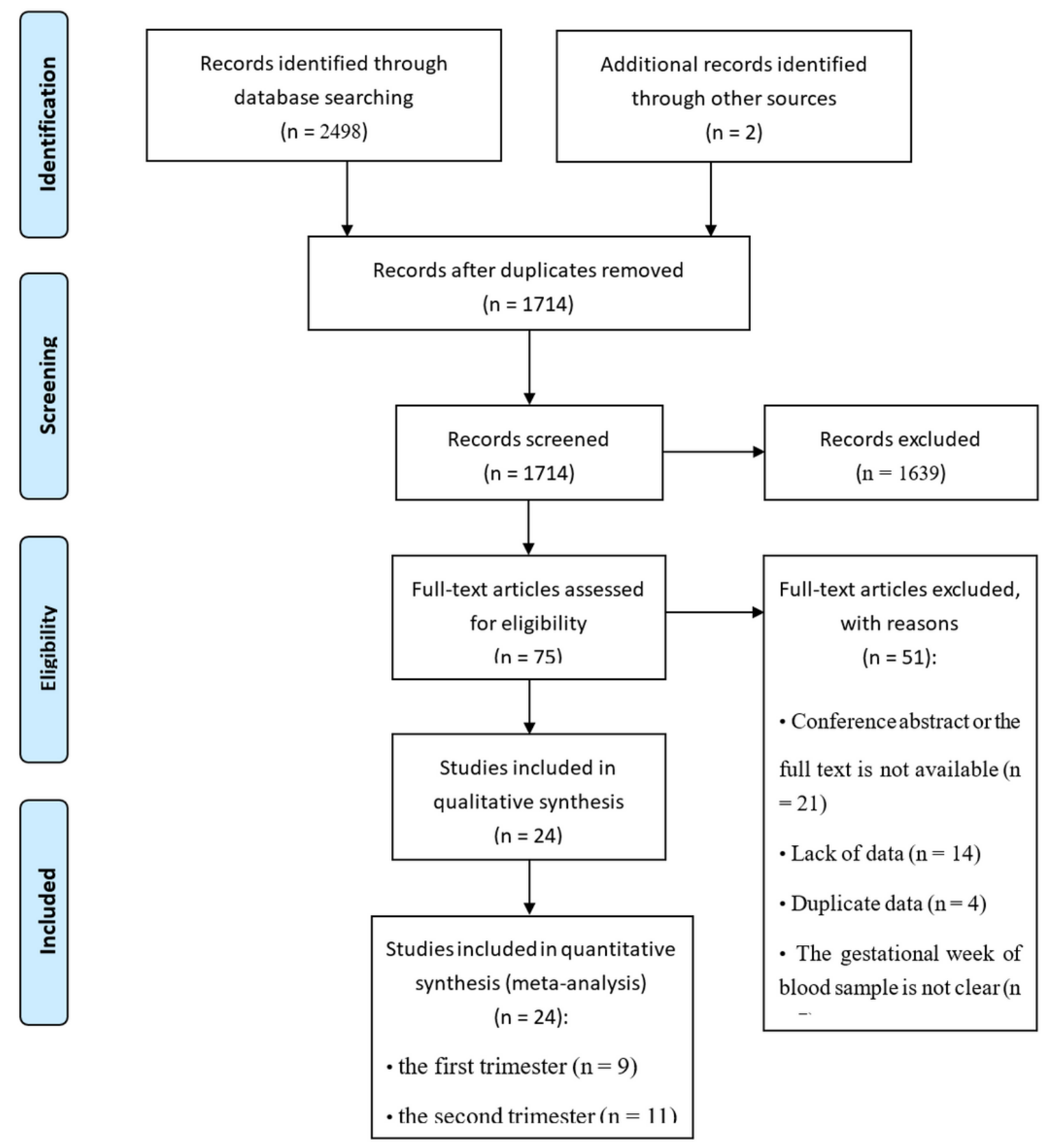

Figure 1

Preferred reporting items for systematic reviews and meta-analyses 
Study

ID

\begin{tabular}{|c|c|c|c|c|}
\hline Ding (2018) & $0.78(0.59,1.05)$ & $49 / 1255$ & \multicolumn{2}{|c|}{$1088 / 2209327.43$} \\
\hline Barebring (2018) & $1.25(0.77,2.00)$ & 23/101 & $466 / 2434$ & 7.00 \\
\hline Zhou (2017) & $1.01(0.56,1.80)$ & $19 / 50$ & $469 / 1239$ & 5.50 \\
\hline Chen (2017) & $1.36(0.44,4.20)$ & $5 / 13$ & $202 / 641$ & 1.21 \\
\hline Tabatabaei (2017) & $1.16(0.78,1.74)$ & $45 / 163$ & $116 / 470$ & 10.55 \\
\hline Flood-Nichols (2015) & $0.98(0.12,8.08)$ & $1 / 11$ & $18 / 194$ & 0.43 \\
\hline Schneuer (2014) & $1.08(0.88,1.32)$ & $145 / 533$ & $1290 / 5004$ & 44.11 \\
\hline Fernández-Alonso (2012) & $0.90(0.39,2.09)$ & $7 / 40$ & $102 / 535$ & 2.86 \\
\hline Baker (2011) & $1.13(0.28,4.45)$ & $3 / 43$ & $8 / 128$ & 0.91 \\
\hline Overall (I-squared $=0.0 \%, p=0.775$ ) & $1.01(0.88,1.16)$ & $297 / 2209$ & $3759 / 32738$ & 8100.00 \\
\hline $\begin{array}{c}1 \\
.118\end{array}$ & 45 & & & \\
\hline
\end{tabular}

\section{Figure 2}

The meta-analysis of the association between maternal vitamin D deficiency in the first trimester and PTB. 


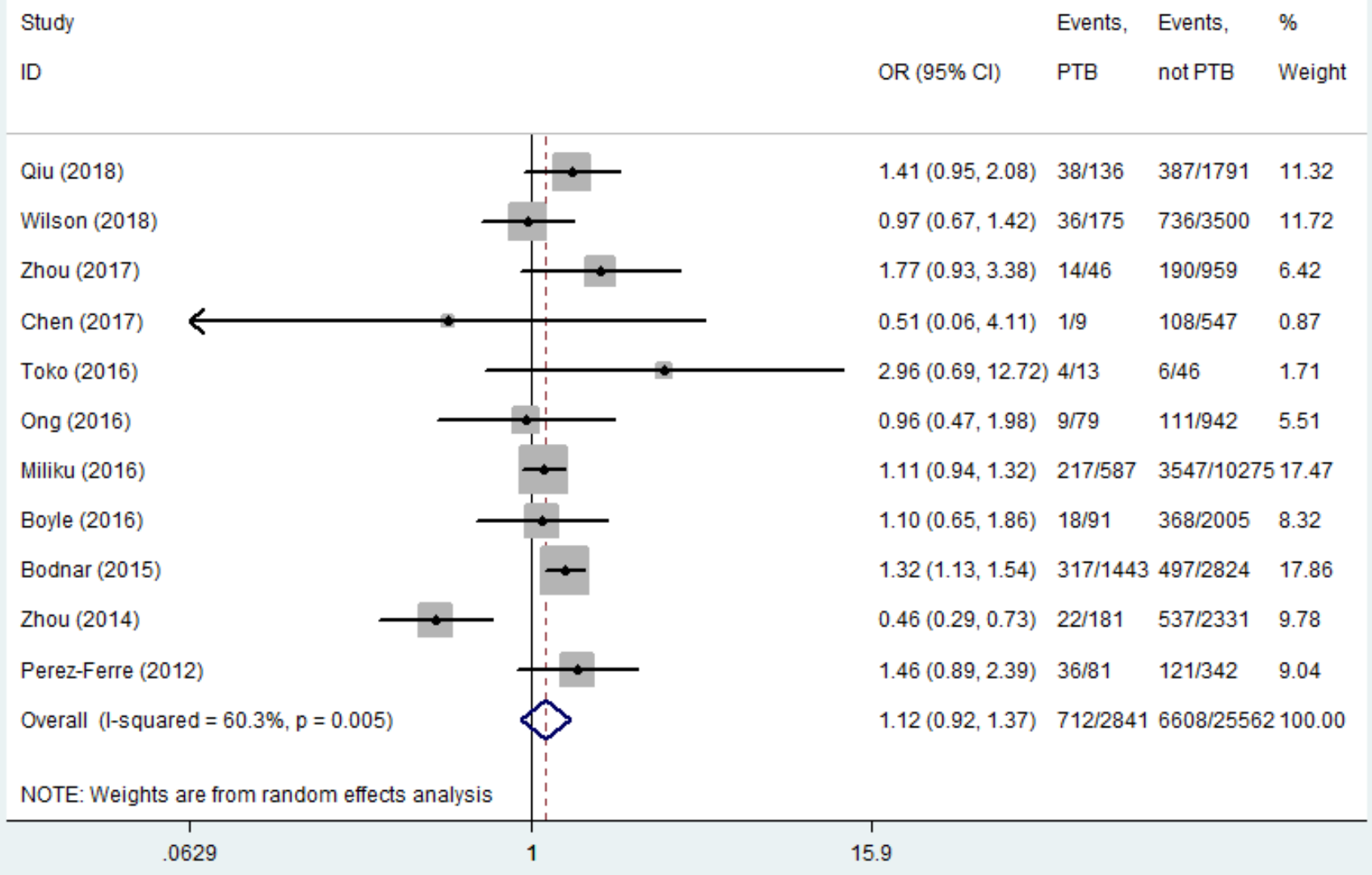

\section{Figure 3}

The meta-analysis of the association between maternal vitamin D deficiency in the second trimester and PTB. 
Study

ID

Kassai (2018)

Barebring (2018)

Zhou (2017)

Chen (2017)

Bhupornvivat (2017)

Baczyńska-Strzecha (2017)

Wang (2015)

Zhu (2015)

Dunlop (2012)

Overall (I-squared $=15.3 \%, p=0.306)$

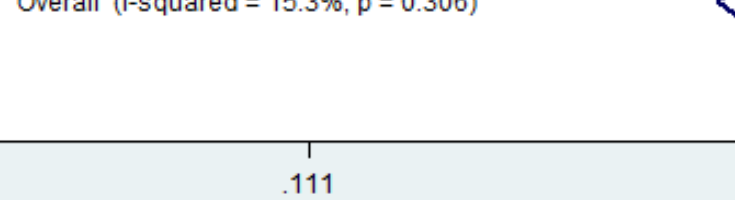

Events, Events, \%

OR $(95 \% \mathrm{Cl})$ PTB not PTB Weight

$1.64(0.86,3.10) 27 / 93 \quad 23 / 115 \quad 7.14$

$0.50(0.26,0.94) 11 / 89 \quad 493 / 2231 \quad 16.22$

$0.79(0.35,1.76) 9 / 28 \quad 383 / 1022 \quad 6.78$

$0.90(0.11,7.32) 1 / 9 \quad 61 / 500 \quad 0.94$

$1.23(0.51,3.00) 16 / 46 \quad 13 / 43 \quad 4.29$

$1.43(0.86,2.38) 51 / 151 \quad 36 / 137 \quad 12.23$

$1.00(0.39,2.57) 9 / 39 \quad 15 / 65 \quad 4.23$

$1.04(0.76,1.43) 71 / 251 \quad 242 / 883 \quad 37.58$

$1.23(0.70,2.16) 38 / 118 \quad 31 / 111 \quad 10.60$

$1.05(0.87,1.27) 233 / 8241297 / 5107100.00$

\section{Figure 4}

The meta-analysis of the association between maternal vitamin D deficiency in the third trimester and PTB. 
Meta-analysis estimates, given named study is omitted

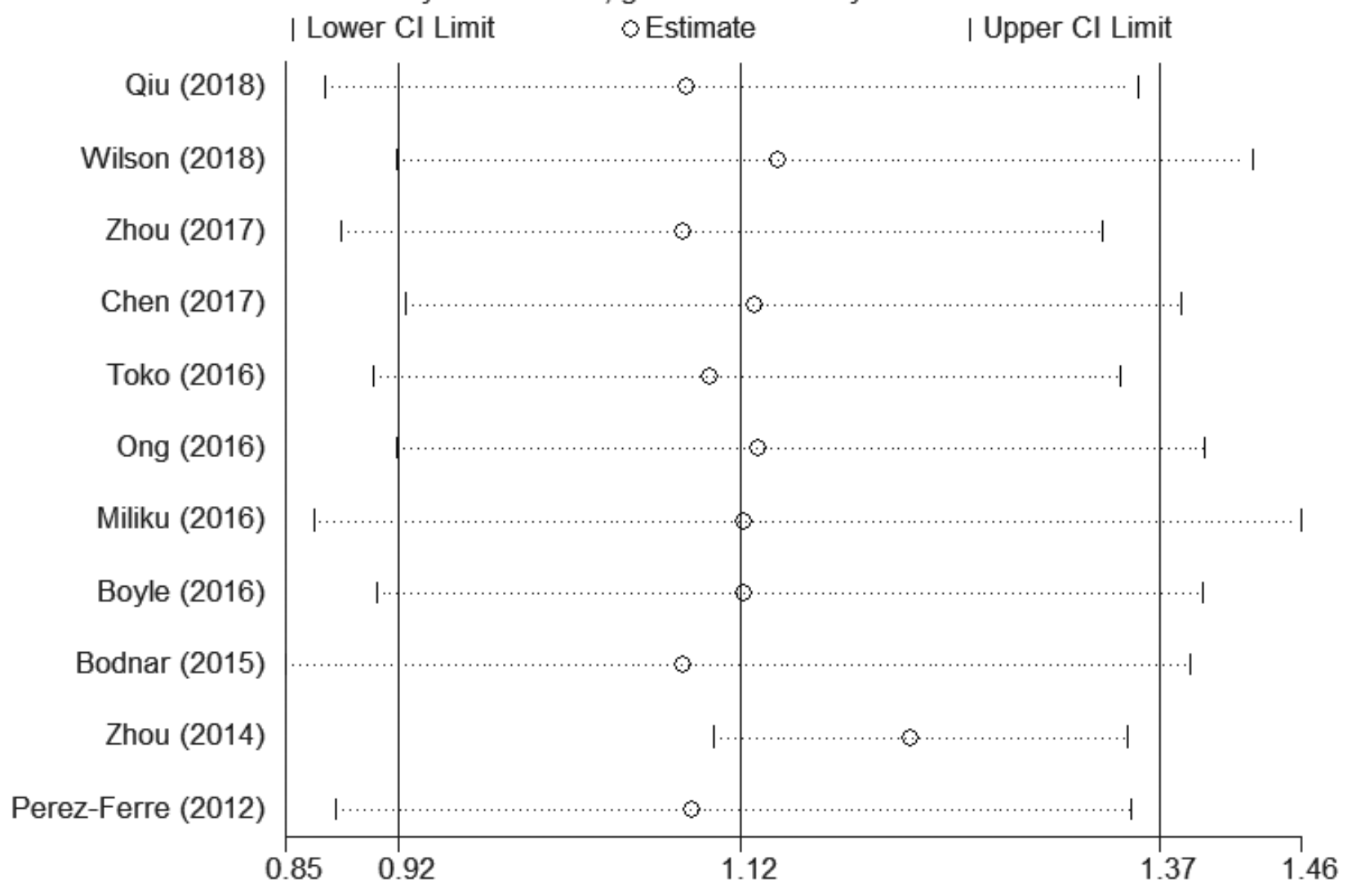

Figure 5

Sensitivity analyses of the association between maternal vitamin D deficiency in the second trimester and PTB. 


$\begin{array}{llll}\text { Study } & & & \text { OR }(95 \% \text { Cl) } \\ \text { Weight }\end{array}$

\section{Figure 6}

The results of subgroup analysis according to different study designs. 


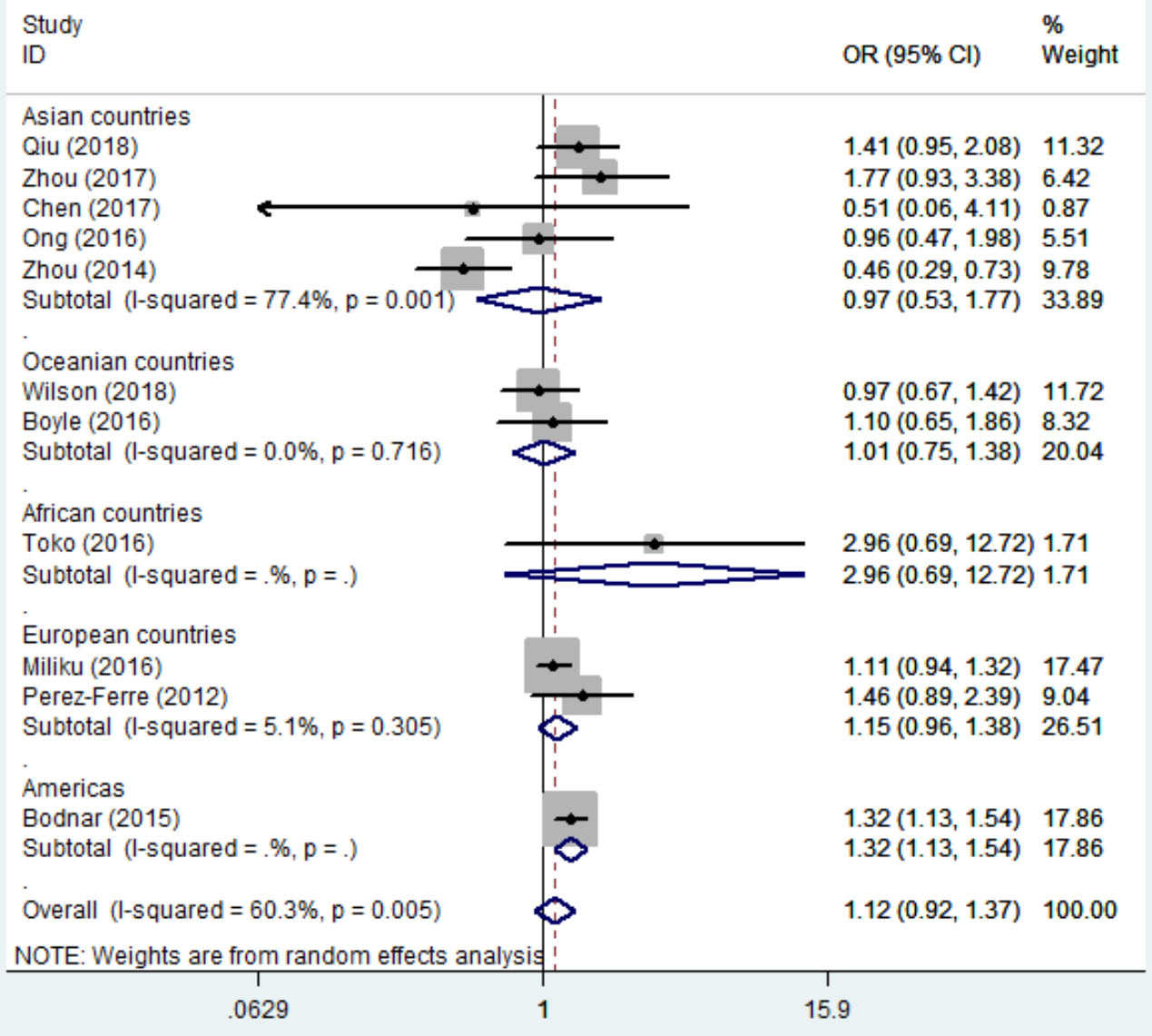

\section{Figure 7}

The results of subgroup analysis according to countries from different continents. 
Begg's funnel plot with pseudo $95 \%$ confidence limits

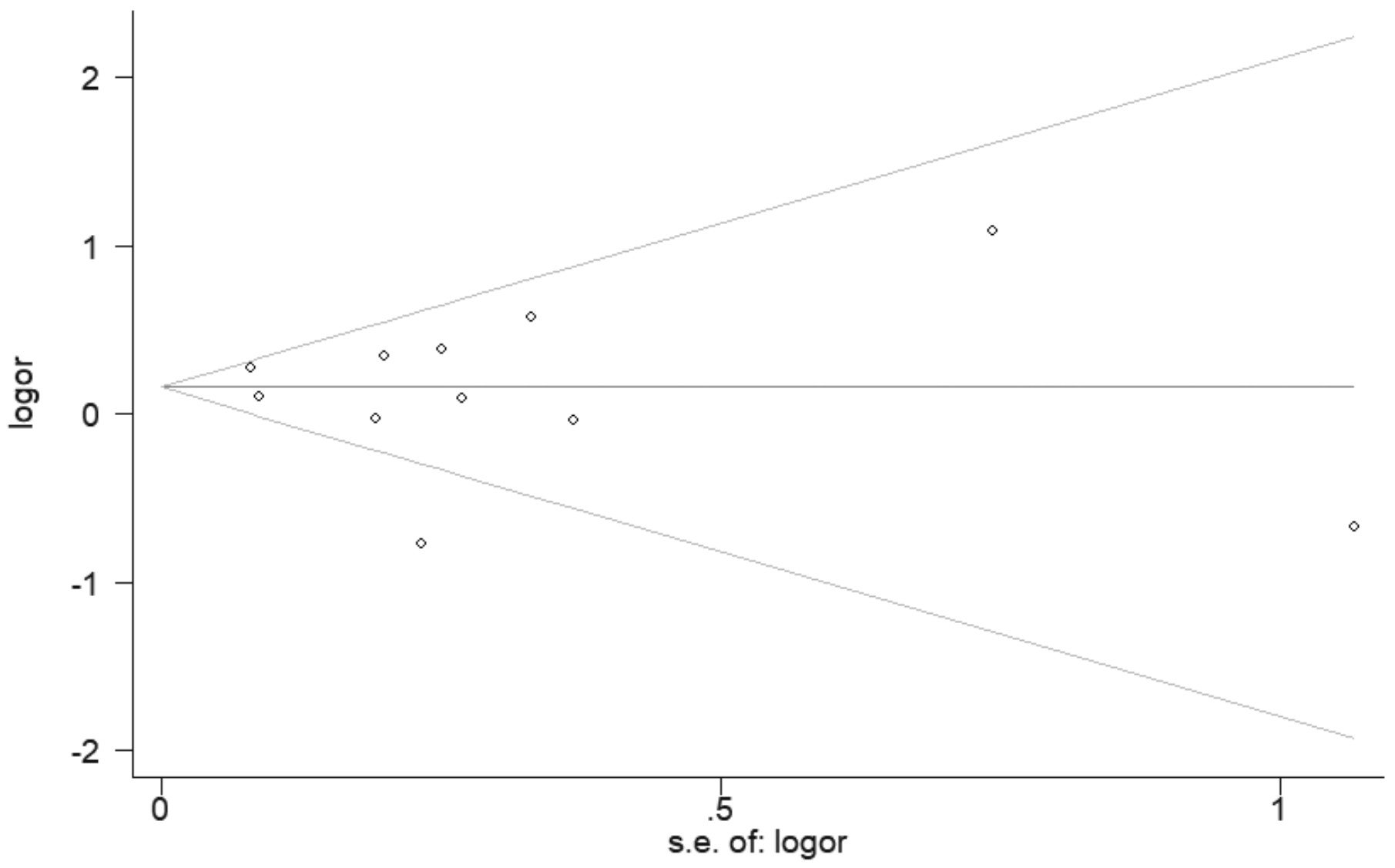

Figure 8

Begg's funnel plot with estimated $95 \%$ confidence intervals for the meta-analysis of the effect of vitamin D deficiency in the second trimester on preterm birth.

\section{Supplementary Files}

This is a list of supplementary files associated with this preprint. Click to download.

- SupplementaryMaterials.docx 